\title{
AFTER THE WASHINGTON CONSENSUS: INTERNATIONAL ASSISTANCE AND GOVERNANCE
}

Aaron Schneider

\begin{abstract}
Resumo
Nossa compreensão da governança em países em desenvolvimento é frágil e, frequentemente, distorcida. $O$ fato de que os investidores estrangeiros estão preocupados com a governança é importante, porém, muitos observadores se limitam a examinar as formas como a governança ajuda o mercado. A governança, de fato, é importante para o desenvolvimento do mercado, mas os governos, às vezes, desempenham outras funções que incluem a substituição do mercado e proteção das normas sociais das transações do mercado. Igualmente, uma noção limitada de governança e métodos de medir segurança, frequentemente se limitam a indicadores quantitativos. Tal abordagem negligencia as seqüências e interações pelas quais os Estados e mercados são construídos e a forma única sócio-cultural pela qual a governança pode operar em diferentes lugares e épocas. Finalmente, é preciso estar atento às ações de Norte que, mesmo bem intencionadas, enfraquecem os governos do Sul. Alguns tipos de ajuda e comércio podem prejudicar a governança ao invés de fortalecêla. Um aspecto fundamental nesta direção é o impacto dos impostos e administração tributária no Sul. Modalidades de ajuda, tais como um projeto de ajuda fragmentado, pouco contribui para fortalecer a governança e, ao contrário, pode enfraquecê-la. Além do mais, a instância em isenção de materiais, serviços e bens adquiridos por meio da ajuda externa pode piorar a governança.
\end{abstract}

Palavras-Chave: Governança; Metodologia; Ajuda Internacional; Impostos; Comércio.

\begin{abstract}
Our understanding of governance in developing countries is weak and frequently misguided. That international donors are paying attention to governance is important, but many observers limit themselves to the ways in which governance enhances markets. Governance is certainly necessary for market development, but governments at times perform other functions, including replacing markets and protecting social norms from market transactions. In addition to a limited notion of governance, methods of measuring governance frequently limit themselves to quantitative indicators. This misses the variety of sequences and interactions by which states and markets are built and the unique socio-cultural ways in which governance is likely to operate at different places and times. Finally, we need to be far more aware of the way in which Northern actions, even guided by good intentions, weaken governance in the South. Certain kinds of trade and aid may actually undermine governance rather than enhance it. Of particular worry is Northern impact on taxes and tax administration in the South. Aid modalities, such as fragmented project aid, do little to enhance governance and may worsen it. Further, insisting on exemptions for materials, services, and incomes purchased with aid, as many donors do, worsens governance.
\end{abstract}

Key-Words: Governance; Methodology; International Aid; Tax; Trade.

REVISTA DEBATES, Porto Alegre, v.2, n.1, p. 5-19, jan- jun.2008. 


\section{Introduction}

In recent years, there has been a welcome shift in the international development community to pay substantive attention to governance. Partly, this reflects an evolution from the unrealistic prescriptions of market fundamentalists who did their best to get the state out of the way - getting prices right. Still, there are problems to resolve. The approach to governance remains distorted by a faith in markets that introduces bias into measurement. Another problem is that the preference for quantitative indicators ignores what we know about the qualitative and interpretive aspects of nation-building, statebuilding, and comparative world history. Finally, our current understanding of governance ignores the ways in which actions of the North and the aid community act to the detriment of governance in the South. The lesson to be drawn is that international institutions have made progress since the 1980 s, but we have a long way to go to integrate governance in a meaningful way.

Part of our difficulty lies in method. In political science, methodological debates have been waged on two fronts. One front is the perestroika front. This battle was taken up forcefully by the perestroika movement of 2000, and the positions have been articulated elegantly by King, Keohane and Verba (1994) and Brady and Collier (2004). On one side stand those who would argue for a singular logic of social science built around formalized, deductive theorizing and quantitative testing. On the other side stand those who bring a diverse toolbox of techniques for conceptualization, causal process tracing, case understanding, and interpretation.

A second debate pits interpretivists against positivists, thereby redividing the social science community into a different set of alliances. On one side are those who take a relativist view of concepts and causal argument and focus their attention on the social construction of meanings (GEERTZ, 1973). On the other side are those who take the process of research as an attempt to build reliable and valid measures 
and causal arguments that can fit and predict our observations (LIEBERSON, 1985).

Interestingly, people who analyze a relatively small number of cases studied comparatively are often switching partners in these debates. For example, as a political scientist engaged in issues of political economy, I frequently find myself entering the perestroika debate with economist colleagues. They typically lump me with anthropologists and sociologists whose work does not begin with formal models and does not always test hypotheses with statistics. By contrast, when I joined a development studies institution, I found myself frequently interacting with sociologists and anthropologists. They charged that I was like economists who are worried about obeying scientific procedures of reliability, validity, and objectivity.

Like me, researchers who specialize in case study and comparison of a small number of cases (small- $\mathrm{N}$ ) often find themselves in bed with one group when the terms of the debate go one way (Is it necessary to deductively theorize, quantitatively measure, and statistically test an argument to prove causality? No) and in bed with another group when the terms of the debate go another way (Can we ever know anything? Yes).

Working in the messy middle provides a particular incentive to bridge these three approaches. The current paper focuses on the notion of governance adopted by international aid organizations. These notions are rooted in institutional economics and represent an advance over previous a-political approaches to development. Yet, a market and a quantitative bias distorts attempts to evaluate governance, missing the ways in which state-building and nation-states differ across times and places. Finally, there is very little reflection on the role of the North in shaping governance in the South. If we take governance seriously, we must not only consider the particular way in which late-developers construct state capacity to reflect their own history and context, we must also change the way in which the North relates to the South. To illustrate this argument, I examine the nature of tax relationships, especially those surrounding international assistance. 


\section{Governance and Institutions}

Since the 1990s bilateral and multilateral actors have introduced sophisticated understandings of governance to their development operations. The Millennium Development Account, the large new fund for United States international assistance, explicitly uses governance measures as criteria for eligibility; the World Bank has invested serious resources in the enterprise, as have regional development banks, such as the Interamerican Development Bank. This is a significant shift from the original limits of the Washington Consensus.

That Consensus was a response to the debt and inflation of the 1980s, in which a basic suspicion of state intervention in the economy was reinforced by the fall of the Soviet Union. In its original formulation, the Washington Consensus included elements that paid heed to governance institutions (e.g. health and education, protect property rights) (WILLIAMSON, 1990). In practice, however, especially in Latin America, the application of the Consensus was to minimize the role of the state. The assumption was that a minimal state would allow markets to emerge naturally.

As 1980 s inflation and debt gave way to 1990 s instability and stagnation, national governments and international institutions became increasingly convinced that governments needed to play essential roles to make markets work. This became the insight that guided attempts to incorporate governance into development operations. Of particular importance was the effort by Wolfensohn to highlight corruption in countries in which the World Bank worked, an initiative that Wolfowitz pursued (to his peril) and Zoellick appears ready to champion (WORLD BANK, 2000). The guiding intuition was that governments needed to provide the right institutional environment to promote development (BURNSIDE and DOLLAR, 1998).

This view of institutions was shaped by institutional economics, which was evolving to specify the kinds of institutions that allowed markets to operate (e.g. NORTH, 1980; WEINGAST, 1995). My position 
is that government enhancing markets is only an important first step. Markets may be useful, but they are not the sole goal of governance, and governance should not solely be evaluated in terms of its contribution to markets.

\section{Market-Bias}

In fact, the emphasis on markets biases the ways in which governance tends to be measured in two ways. First, there is a tendency to assume markets flourish where governments do not - good governance is measured as minimal government. Second, where government is necessary, it is only in its role of improving markets ignoring functions that replace markets or protect social rules from market operations.

The belief in minimal governance leads to attempts to measure what government does not do (e.g. red tape, corruption, barriers to trade). One example is the attempt to measure regulatory quality and rule of law, which mostly looks for evidence that regulations and legal rules do not complicate the work of businesses (KAUFMANN et al, 2002, 2003, 2005). The implication, of course, is that governments that do less of these things automatically allow the space for markets to emerge. This reflects a desire for certain policy outcomes (small government) rather than governance itself. In fact, it may ignore the important ways in which more government makes markets work (RODRIK, 1997) or governments are necessary to establish markets where none exist (ENSMINGER, 1996).

Spurious validation of small government measures are produced as an artifact of the people surveyed, such as businesspeople and riskrating agencies. A shared preference for small governance may be driving results, rather than accurate measures of governance. To improve such measures, the same issues would need to be asked of different publics (KURTZ and SCHRANK, 2007).

A second problem appears in the failure to measure instances in which markets are replaced by bureaucratic or social processes. The most obvious example would be the evaluation of East Asian 
developmental states. Despite attempts to interpret these as examples of minimal government intervention (WORLD BANK, 1993), most observers conclude that these were cases in which government bureaucracy substituted for market processes, getting prices wrong such that development could advance (AMSDEN, 2001; WADE, 1990).

Examples of social processes substituting for market processes are evident in any number of policy areas in which markets offend cultural or social sensibilities. Many years ago, Polanyi (2001) spoke of a "double movement," in which market operations and social operations negotiated boundaries over what can be bought and sold (2001). Contemporary conflicts over religion and family structure offer examples of the ways in which societies define the boundaries between market operations and social norms. Any measure of governance needs to be sensitive to the capacity of the state to enforce these boundaries, which necessarily differ across societies.

\section{Quantitative Insufficiency}

While there is no necessary correlation between the international aid architecture and specific methodologies for measurement, an affinity for quantitative techniques has emerged. This has produced a number of useful quantitative databases and metadatabases (World Bank website; DATAGOB - IADB; Millenium Challenge Account). On the other hand, quantitative measures, even if conducted perfectly, have skated over aspects of governance that are more evident in qualitative and interpretive research.

Qualitative work on governance has evolved through a series of classic studies that is mostly, though not exclusively, focused on countries in the North, where state capacity is arguably higher (eg. TILLY, 1992). These studies traced the combination of factors that came together as rulers emerged, centralized power within a given territory, consolidated control, legitimated their rule, and built states. The general argument for using a comparative and qualitative approach to these questions is that contexts, sequences, and external factors vary, so it is only possible to understand governance by tracing the process by which 
states emerged in each place. Otherwise, we miss the differences in the nature of governance in early developers, late developers, and the latelate developers of today. This points not to single or even multiple dimensions, but rather to alternative combinations of dimensions, in which multiple paths to similar outcomes are possible (state-building, in this case) (RAGIN, 1987).

Interpretive work produces an approach to governance that is equally distinct from quantitative analysis. In fact, the end of the Cold War and processes of globalization have provoked a resurgence in interpretive and constructive approaches to governance, much of it working out of international relations approaches to norms and regimes (WENDT, 1998). The starting point for much of this research is to step backwards to ask what we mean by the study of governance. What is it about a particular moment in world history in which the world's landmass is divided into a series of territorially bounded units that forge identities, establish administrative structures, and attempt to manage social, economic, and political challenges?

The research enterprise laid out by interpretive approaches seeks to understand how the idea of governance emerged when and where it did, how it is understood by different cultures and societies, and whether or not a different organization of the world might avoid some of the horrors experienced under the current system of states (ANDERSON, 1983). The process of statebuilding in its current form emerged in Europe, where capitalism, states, and Western culture came together to produce national-states - shared identity, centralized bureaucracies, and market expansion. Other countries had different initial conditions, and importing the core characteristics of nationhood from Europe created only diminished subtypes of Western European states, lacking shared identity, centralized bureaucracy, or consolidated markets.

The point is that quantitative measures of governance, though useful for cross-national comparison and hypothesis testing, fail to capture the sequences and interactions associated with statebuilding (the qualitative view) or the culturally-bound and time-bound definition of Western European governance (the interpretive view). 
To apply the concept of governance to the way we design or allocate aid, it would make sense to keep qualitative and interpretive insights in mind. Most importantly, both of these approaches take seriously not only the measurement of governance, but also the notion that it is wrapped closely into how it evolves over time in different contexts and from different perspectives.

\section{Northern Impacts on Southern Governance}

This last point brings us to the real oversight in current treatments of governance. Most attempts to measure governance assume that it is something incomplete in developing countries, in which our job is to measure its shortcomings and offer suggestions on how to improve. This avoids the question of culpability in creating poor governance, in which the North deserves plenty of the blame, and more generally fails to take into account the causal processes that produce weak governance.

This is not the place to list all the ways in which the North has intentionally undermined governance in the South. Such a review would have to begin with the long history of colonialism and ongoing interventions in which our leaders claimed (hollowly) to be beneficent. Northern countries have not been shy to undermine governance in places that are rich in natural resources or that occupy geopolitically important positions, nor do Northern countries decline to produce and proliferate the means of coercion to unsavory governments seeking to sustain their rule.

The discussion here is focused on the ways the North undermines governance in the South even when attempting to help. Often, this occurs because our understanding of governance is weak. One example is in terms of the international financial architecture, replete with high speed transactions, capital account liberalization, and permissive national regulations. Among this international architecture are tax havens, which the OECD listed as places in which secrecy, low regulation, and low tax allow wealthy people in poor countries to hide their wealth, much of it gained corruptly. Some of these havens are in 
the South (e.g. Cayman Islands), but others are in the North (e.g. Isle of Jersey), and they have expanded greatly in the last 25 years of capital account liberalization. Further, the institutions that govern accounting standards and could regulate illicit capital flows are established and managed in the North, yet we have not equipped them to protect against governance decay in the South (OECD, 1998).

In addition, simply by engaging in certain types of trade with poor countries, we systematically undermine governance. Some of the products we buy are illegal, such as drugs and illegal diamonds, yet there is little sign that consumption in the North is dropping (NAIM, 2006). Instead, we focus our efforts against these products in military solutions in the South, with predictable effects empowering military hierarchies within governments that already have weak civilian oversight and are poorly linked to civil society.

Even trade in products that are not illegal may do little to improve governance in the South. Consumption of natural resources, especially oil and gas, offers opportunities for huge profit, increasing in recent years. These profits are easily captured by states, state enterprises, and their leaders, making it possible for Southern governments to finance exorbitant elite consumption, and if necessary repression, even as they ignore their citizens (ROSSER, 2006).

These examples suggest that the North has been unable to regulate markets that harm governance in the South. More worrying is the fact that even when we explicitly set out to aid Southern governance, we rarely succeed. Despite significant ink spilled on the topic, donors have been unable to coordinate their efforts in the countries they work, complicating administration and weakening governance (BIRDSALL, 2007). Nor have they brought donor funds into formal government processes, preferring instead to create parallel processes and bureaucracies through project and program aid rather than sector-wide or budget support. Research into the relationship between donor fragmentation and governance suggests that as aid increases, donors proliferate, creating more negotiations, more conditions, and more administrative costs (ACHARYA et al, 2006). This 
burdens weak governments, and evidence suggests that as aid fragments, governance quality declines (KNACK and RAHMAN, 2004).

Another example of doing harm while attempting to do good is evident in the area of tax. The international aid community is increasingly cognizant of the importance of tax for promoting development. To this end, an increasing amount of resources are being spent on tax administration, tax reform, and tax capacity in the South. This is a good sign, and an improvement from the notion that less tax is better for development. Yet, at the same time as Northern countries contribute to tax capacity with their aid projects, they undercut it in several ways.

Northern companies, often aided by their embassies and governments, press for tax exemptions in the countries in which they do business (JACKSON, 2005). Where they cannot gain legal exemption, they evade, using mechanisms like transfer pricing. Such evasion has been estimated to cost developing countries approximately $\$ 250$ billion a year, almost four times the amount needed to meet the MDGs (Millenium Development Goals). Much evasion is done by elites in the South, who are the holders of wealth, but it is also Northern companies that find ways not to pay tax in the South. Overseeing this evasion is made even more difficult by exemptions written into tax laws, such as exemptions for export zones.

It is not only Northern companies that perforate tax administration. Bilateral and multilateral aid organizations often press for exemptions on customs duties, VAT (value added tax), sales, excise, and other indirect taxes. Also, personnel are frequently exempted from income taxes and projects exempted from profit taxes. This can add up to a significant amount, for example it has been estimated at 18 percent of project financing in Niger and 10 percent of all tax revenue in 2002 (INTERNATIONAL TAX DIALOGUE, 2006). Developing countries are essentially forced to choose between protecting the integrity of their tax systems and accepting aid.

The reasons donors claim for these exemptions have been various. In some cases, internal policy prohibited using loans and aid to 
finance taxes. The World Bank changed this policy in 2004, allowing payment of tax on reasonable expenses on a case by case basis, a policy subsequently adopted by the IADB (Interamerican Development Bank), ADB (Asian Development Bank), and French Development Agency (INTERNATIONAL TAX DIALOGUE, 2006, p. 5).

Other donors have resisted. Some point to their desire for control over the goods purchased with each transfer. Better to build ten schools than to build nine and transfer the remaining amount to recipient governments in the form of taxes, even if those funds might be used to build another school. This violates the ongoing debate about the fungibility of aid (DEVARAJAN and SWOOP, 1998), but may reflect donor desires to bypass governments they consider corrupt or unsavory. It may also reflect concerns related to the reasonableness of national tax legislation in terms of rates, discrimination against aid-financed projects, or the incidence of tax, which may fall on donors or recipients.

These fears are probably more evident for bilateral donors, who are charged with conflicting imperatives. On one hand, they seek to promote development in the countries in which they work. On the other hand, they must defend their allocations to the public in their own countries, and they may feel that aid to recipient coffers through tax is somehow less defensible than aid directly to projects. Further, aid agencies may be asked to pursue foreign policy imperatives, such as empowering civil society at the expense of government, precluding transfers that might be taxed.

Donors would not insist on these exemptions if they took governance implications seriously. Exemptions increase the transaction costs of international assistance, both for donors and for recipients, as exemptions are often different from one donor to another and one country to another. Exemptions also complicate tax administration, making both compliance and enforcement more difficult. Exemptions to the VAT are particularly complicated, requiring credits or refunds in the case of zero ratings. Further, by opening holes in the tax system, exemptions provide opportunities for tax fraud and economic distortion. Politically, opening exemptions creates likely pressure for other actors to 
press for their own exemptions, and donors pressing to eliminate other exemptions would do well to follow their own advice.

Most significantly, exemptions weaken tax capacity, removing funds from the public coffers that might otherwise be there. Donors are increasingly switching to budget support, suggesting greater confidence in recipient public finance management, yet they appear unwilling to pay taxes into those same systems of public finance management. If donors took their own role in shaping Southern governance seriously, they would not insist on exemptions that weaken the very governments they intend to aid.

\section{Conclusion}

Most donor attempts to incorporate governance into international aid is that governance in the South is weak and needs to be improved if markets are to develop. This is certainly true, but we do a disservice if we limit our understanding in this way. There are times when governments need to replace markets and times in which governments need to protect social norms from market operations. In addition, we need to be savvy about the variety of sequences and interactions by which states and markets are built and the unique socio-cultural ways in which governance is likely to operate at different places and times. None of this is particularly evident in the quantitative studies of governance favored by international donors.

Finally, we need to be far more aware of the way in which Northern actions, even guided by good intentions, weaken governance in the South. Certain kinds of trade and aid may actually undermine governance rather than enhance it. Of particular worry is Northern impact on taxes and tax administration in the South. Aid modalities, such as fragmented project aid, do little to enhance governance and may worsen it. Further, insisting on exemptions for materials, services, and incomes purchased with aid, as many donors do, worsens governance.

Aaron Schneider is assistant professor of Political Science, Tulane University. 
E-mail: aarons@tulane.edu

\section{References}

ACHARYA, A. K.; LIMA, A. F. de; MOORE, M. Aid Proliferation: How responsible are the donors? Journal of Development Studies, v.1, n.42, p. $1-21,2006$.

AMSDEN, A. The Rise of "the Rest": Challenges to the West from LateIndustrializing Economies. Oxford: Oxford University Press, 2001.

ANDERSON, B. Imagined Communities. London: Verso, 1983.

BIRDSALL, N. Do No Harm: Aid, Weak Institutions and the Missing Middle in Africa. Development Policy Review, v. 25, n. 5, p. 575-598, Sep 2007.

BRADY, H. E.; COLLIER, D. (Eds.). Rethinking Social Analysis: Diverse Tools. Shared Standards. New Yok: Rowman and Littlefield, 2004.

BURNSIDE, C.; DOLLAR, D. Aid, the Incentive Regime, and Poverty Reduction. Washington, D. C.: World Bank, 1998. (World Bank Policy Research, Working paper n. 1937).

DEVARAJAN, S.; SWOOP, V. The Implications of Foreign Aid Fungibility for Development Assistance. Washington, D. C.: World Bank, 1998. (World Bank Policy Research, Working paper n.2022).

ENSMINGER, J. Making a Market: The Institutional Transformation of an African Society. Cambridge: Cambridge University Press, 1996.

GEERTZ, C. The Interpretation of Cultures: Selected Essays. New York: Basic Books, 1973.

INTERNATIONAL TAX DIALOGUE. Tax Treatment of Donor Financed Projects. Brussels: ITD, 2006. (ITD Discussion Paper, n. 241).

JACKSON, J. T. Globalizers: Development Workers in Action. Baltimore: Johns Hopkins University Press, 2005.

KAUFMANN, D.; KRAAY, A. Growth without Governance. Economía, v.1, n.3, p.169-215, 2002.

KAUFMANN, D.; KRAAY, A.; MASTRUZZI, M. Governance Matters III: Governance Indicators for 1996-2002. Washington, D.C.: World Bank, 2003. 
. Governance Matters IV: Governance Indicators for 1996-2004. Washington, D.C.: World Bank, 2005.

KING, G.; KEOHANE, R. O; VERBA, S. Designing Social Inquiry: Scientific Inference in Qualitative Research. Princeton: Princeton University Press, 1994.

KNACK, S.; RAHMAN, A. Donor Fragmentation and Bureaucratic Quality in Aid Recipients. In 2004 WORLD DEVELOPMENT REPORT, Washington, D.C., 2004. Background paper. Washington, D.C.: WDR, 2004.

KURTZ, M.; SCHRANK, A. Growth and Governance: Models, Measures, and Mechanisms. Journal of Politics, v. 2, n. 69, p. 538-564, 2007.

LIEBERSON, S. Making it Count: The Improvement of Social Research and Theory. Berkeley: University of California Press, 1985.

NAIM, M. Illicit: How Smugglers, Traffickers and Copycats are Hijacking the Global Economy. New York: Doubleday, 2006.

NORTH, D.C. Institutions, Institutional Change, and Economic Performance. New York: Cambridge University Press, 1980.

OECD. Harmful Tax Practices: An Emerging Global Issue. Paris: OECD, 1998.

POLANYI, K. The Great Transformation. Boston: Beacon Press, 2001.

RAGIN, C. C. The comparative method moving beyond qualitative and quantitative strategies. Berkeley: University of California Press, 1987.

RODRIK, D. Has Globalization Gone too Far? Washington, D.C.: International Institute of Economics, 1997.

ROSSER, A. The Political Economy of the Resource Curse: A Literature Survey. Brighton: Insitute of Developement Studies, 2006. (IDS Working Paper 268).

TILLY, C. Coercion, Capital and European States, A. D. 990-1992. New York: Blackwell Publishing, 1992. (Studies in Social Discontinuity).

WADE, R. Governing the Market: Economic Theory and the Role of Government in East Asian Industrialization. Princeton, NJ: Princeton University Press, 1990.

WEINGAST, B. R. The Economic Role of Political Institutions: MarketPreserving Federalism and Economic Development. Journal of Law Economics and Organization, v.1, n.11, p.1-31, 1995. 
WENDT, A. Social Theory of International Politics. Cambridge: Cambridge University Press, 1998.

WILLIAMSON, J. What Washington Means by Policy Reform. In: WILLIAMSON, J. (Ed.). Latin American Adjustment: How Much Has Happened? Washington, D.C.: Institute for International Economics, 1990. p. 7-20.

WORLD BANK. The East Asian Miracle: Economic Growth and Public Policy. Oxford: Oxford University Press, for the World Bank, 1993.

Helping Countries Combat Corruption: Progress Since 1997. Washington, D.C.: World Bank, 2000. 